\title{
Steroids from The Stem Bark of Dysoxylum nutans (Meliaceae) and Their Cytotoxic Effect Against MCF-7 Breast Cancer Cell Lines
}

\author{
Tri Mayanti $^{1^{*}}$, Nur Insani Amir ${ }^{1}$, Dewa Gede Katja ${ }^{2}$, Sofa Fajriah ${ }^{3}$, Ahmad Darmawan ${ }^{3}$, \\ Unang Supratman $^{1,4}$, Khalijah Awang ${ }^{5}$, Yoshihito Shiono ${ }^{6}$ \\ ${ }^{1}$ Department of Chemistry, Faculty of Mathematics and Natural Sciences, \\ Universitas Padjadjaran, Jatinangor 45363, Sumedang, Indonesia \\ ${ }^{2}$ Department of Chemistry, Faculty of Mathematics and Natural Sciences, Sam Ratulangi University, \\ Kampus Kleak, Manado, 95115, North Sulawesi, Indonesia \\ ${ }^{3}$ Research Central for Chemistry, Indonesian Science Institute, PUSPITEK, \\ Serpong, 15320, Tangerang, Indonesia \\ ${ }^{4}$ Central Laboratory of Universitas Padjadjaran, Jatinangor 45363, Sumedang, Indonesia \\ ${ }^{5}$ Department of Chemistry, Faculty of Science, University of Malaya, Kuala Lumpur 59100, Malaysia \\ ${ }^{6}$ Department of Food, Life, and Environmental Science, Faculty of Agriculture, \\ Yamagata University, Tsuruoka, Yamagata 997-8555, Japan \\ *Corrsponding author: t.mayanti@unpad.ac.id
}

Received: June 2020; Revision: June 2020; Accepted: August 2020; Available online: December 2020

\begin{abstract}
Three steroids, $3 \alpha$-hydroxystigmast-5(6), 22-diene-7-one (1), stigmasterol (2) and 3-hydroxy-7 $\beta$ methoxystigmast-5(6)-ene (3), were isolated from the stem bark of Dysoxylum nutans. The chemical structures were identified by spectroscopic data, which includes IR, 1D-NMR, 2D-NMR, and HR-TOFMS as well as by comparing previously reported spectral data. Compounds 1-3 were tested for cytotoxic effect against MCF-7 breast cancer cell lines and compound $\mathbf{1}$ showed the strongest cytotoxic activity with an $\mathrm{IC}_{50}$ value of $20.13 \pm$ $0.06 \mu \mathrm{M}$.
\end{abstract}

Keywords: Cytotoxic activity, Dysoxylum nutans, MCF-7 breast cancer cells, Meliaceae, stigmastane-type steroids.

DOI: https://doi.org/10.15408/jkv.v6i2.15976

\section{INTRODUCTION}

The genus Dysoxylum belongs to the Meliaceae family, which consists of over 80 species (Hu et al., 2014a), that are widely distributed in India, China, Malaysia, Indonesia, Australia, and New Zealand (Luo et al., 2002; Cao et al., 2013). In addition, it is rich in limonoids (Zhou et al., 2015; Han et al., 2015), tirucallane-type triterpenoids (Hu et al., 2014a; Luo et al., 2002; Huang et al., 2011), lanostanetype triterpenoids (Jiang et al., 2015; Zou et al., 2017; Tang et al., 2012), dammarane-type triterpenoids (Cao et al., 2013; Yan et al., 2014a), and steroids (Yan et al., 2014a; Wah et al., 2013, Govindachari et al., 1999).

Previous investigation reported that compounds isolated from the genus Dysoxylum exhibit diverse biological activities, which includes antitumor (Cao et al., 2013), antimicrobial (Gopalakrishnan et al., 2015), antibacterial ( $\mathrm{Hu}$ et al., 2014b), antiparasitic (Lakhsmi et al., 2007), post-coital contraceptive (Das et al., 2013), and cytotoxic (Han et al., 2015; Ragasa et al., 2014; Kurimoto et al., 2011; Zhang et al., 2010; Ismail et al., 2009; Farabi et al., 2017).

As part of our investigation for anticancer substances from Indonesian Dysoxylum plants, methanol extract from dysoxyl nutans showed strong cytotoxic activity against MCF-7 breast cancer cell lines in vitro. D. nutans, which is a high plant and widely distributed in South East Asia (Luo et al., 2002; Cao et al., 2013). The plant is used in Indonesian for traditional medicine for fevers, infected wounds and skin diseases (Heyne, 1982). Although secondary 
metabolites of other Dysoxylum species have already been investigated, the phytochemical investigation of $D$. nutans has not yet been reported. The isolation, structure determination and cytotoxic effect of these isolated compounds are described.

\section{MATERIALS AND METHODS General Experimental Procedure}

Melting points were measured using an IA9000 electrothermal melting point apparatus (Bibby Scientific Limited, Staffordshire, UK). The optical rotations were recorded on a PerkinElmer 341 polarimeter (Waltham, MA, USA). The UV spectra was obtained using a TECAN Infinite M200 pro, with methanol (Switzerland). The IR was recorded on a SHIMADZU IR Prestige-21 in $\mathrm{KBr}$ (Kyoto, Japan). Mass spectra were measured using a Water QTOF HR-MS $\mathrm{XEV}^{\mathrm{otm}}$ mass spectrometer (Waters, Milford, MA, USA). The NMR data were recorded on Bruker $600 \mathrm{MHz}$ (Billerica, MA, USA) and JEOL ECZ-600 spectrometer (Kyoto, Japan) at $600 \mathrm{MHz}$ for ${ }^{1} \mathrm{H}$ and $150 \mathrm{MHz}$ using tetramethylsilane as an internal standard. Column chromatography was conducted on silica gel 60 (70-230 mesh and 230-400 Mesh) (Merck, Darmstadt, Germany). TLC plates were precoated with silica gel $\mathrm{GF}_{254}$ (Merck, Darmstadt, Germany $0.25 \mathrm{~mm}$ ) and evidence was obtained by spraying with $10 \%$ sulphuric acid in ethanol, followed by heating.

\section{Plant Material}

The stem bark of $D$. nutans was obtained in Bogor Botanical Garden, West Java Province, Indonesia in August 2017. The plant specimen was deposited at Herbarium with collection number, III. F. 98.

\section{Extraction and Isolation}

The dried grounded stem bark $(900.0 \mathrm{~g})$ was extracted using methanol exhaustively (10 L) at room temperature for 5 days. Removal of the solvent on a rotary evaporator gives an extract of concentrated methanol (111.6 g). The concentrated methanol extract was first suspended in water and sequentially separated using $n$-hexane and ethyl acetate, and directly evaporated to give $n$-hexane $(20.5 \mathrm{~g})$ and ethyl acetate $(10.5 \mathrm{~g})$, respectively. The $n$-hexane soluble fraction $(20.0 \mathrm{~g})$ was fractionated by vacuum liquid chromatography (VLC) on silica gel using a gradient $n$-hexane-ethyl acetate to give 8 fractions $(\mathrm{A}-\mathrm{H})$. Fraction $\mathrm{E}$ (3.9 g) was separated by column chromatography on silica gel using 3\% mixtures of $n$-hexane-ethyl acetate as eluting solvents (100:0-70:30) to give 8 subfractions (E1-E8). Sub-fraction E5 (1.1 g) was further separated by column chromatography on silica gel, with $n$-hexane- ethyl acetate (2\% stepwise) as solvent system to give 7 subfractions (E5a-E5g). Similarly, sub-fraction E5e $\left(\begin{array}{ll}0.1 & \text { g}\end{array}\right)$ was separated by column chromatography on silica gel, with $1 \%$ mixtures of $n$-hexane- ethyl acetate as a solvent (100:080:20) to give $1(13.0 \mathrm{mg})$. Sub-fraction E5f was separated by column chromatography on silica gel, with $n$-hexane: ethyl acetate $(8: 1)$ as a solvent to give 2 ( $3.0 \mathrm{mg}$ ).

The ethyl acetate extract (10.5 g) was separated by vacuum liquid chromatography with $10 \%$ mixture of $n$-hexane-ethyl acetatemethanol (10:0-7:3) as a solvent to give 4 fractions (A-D). Fraction D (4.6 g) was separated by column chromatographed on silica gel with chloroform-ethyl acetat $(9: 1)$ as a solvent system to give $\mathbf{3}(2.0 \mathrm{mg})$.

\section{Bioassays of Cytotoxic Activity (Skehan et al., 1990)}

MCF-7 cells were grown in 96-well plates with initial cell densities of approximately $3 \mathrm{x}$ $10^{4} \mathrm{~cm}^{-3}$. After 24 hours of incubation for cell growth, various concentrations of the sample were added. Furthermore, the sample was first dissolved in DMSO at the required concentration. The next six desired concentrations were prepared using PBS (phosphorus buffer solution, $\mathrm{pH}=7.30-7.65$ ). The control wells only accept DMSO, and the test was stopped after an incubation period of 48 hours by adding PretoBlueTM Cell Viability Reagent and the incubation was further continued for 1-2 hours until the color change is observed. Optical density was read using a micro plate reader at $570 \mathrm{~nm}$. $\mathrm{IC}_{50}$ values were taken from cell charts of the percentage life plotted compared to the control (\%), and the concentration of the tested compounds $(\mu \mathrm{M})$. An $\mathrm{IC}_{50}$ value is the concentration needed to inhibit 50\% growth. Each test and analysis was carried out in triplicate and average.

\section{RESULTS AND DISCUSSION}

The concentrated methanol extract from the dried stem bark of $D$. nutans was extracted with $n$-hexane and ethyl acetate. The $n$-hexane extract was separated by vacuum-liquid chromatography (VLC) on silica gel 60 by 
gradient elution. The VLC fraction was separated by column chromatography on silica gel to give compounds 1-2. The ethyl acetate was prepared as described for compounds 1-2 and give compound $\mathbf{3}$ (Figure 1).

\section{3 $\alpha$-hydroxystigmast-5(6),22-diene-7-one (1)}

White crystal; m.p. $138-140{ }^{\circ} \mathrm{C}$; $[\alpha]^{28.4}{ }_{\mathrm{D}}^{-}$ $0.67^{\circ}\left(c 0.3, \mathrm{CHCl}_{3}\right)$; IR (KBr) $v_{\max } 3423,2926$, $1736,1462,1040 \mathrm{~cm}^{-1}$; NMR $\left(\mathrm{CDCl}_{3}, 600 \mathrm{MHz}\right.$ for ${ }^{1} \mathrm{H}-\mathrm{NMR}$ and $150 \mathrm{MHz}$ for ${ }^{13} \mathrm{C}-\mathrm{NMR}$ ) see Table 1; HR-TOFMS $\mathrm{m} / z$ 449.3553 [M+Na] ${ }^{+}$ (Calcd. for $\mathrm{C}_{29} \mathrm{H}_{46} \mathrm{O}_{2}, m / z$ 426.3558).
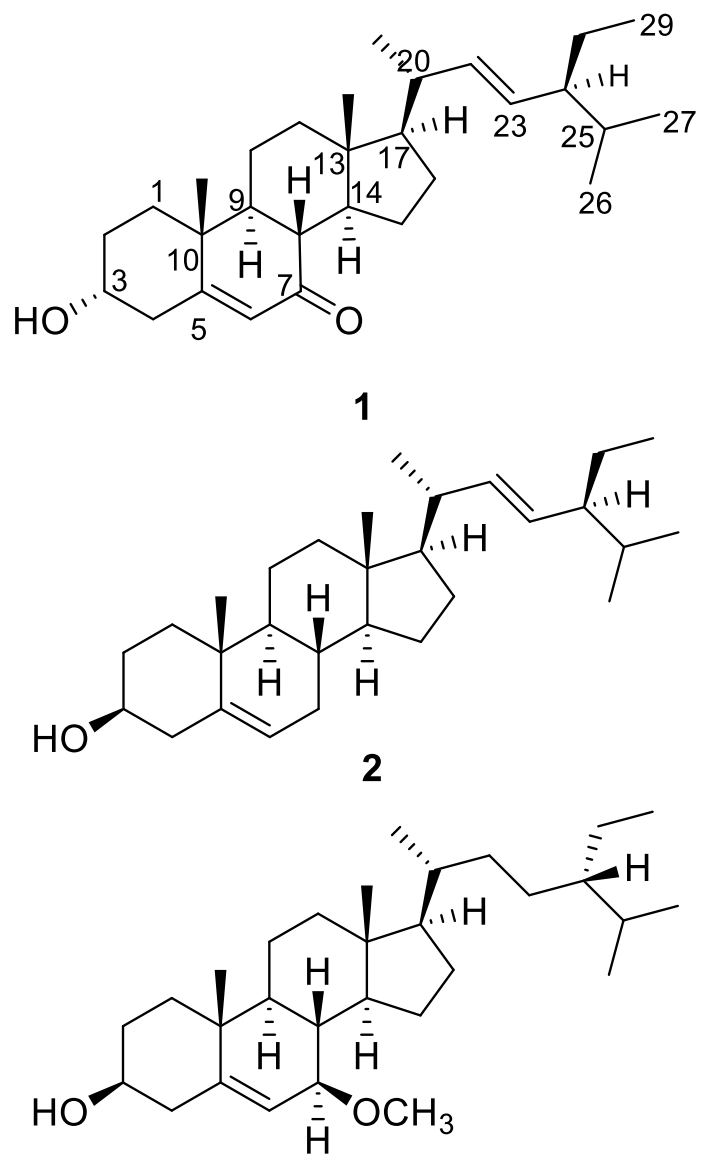

3

Figure 1. Structures of Compounds 1-3.

Compound 1 was obtained as a white crystal with m.p. $138-140{ }^{\circ} \mathrm{C}$ and $[\alpha]^{\mathrm{D}} 28.4-0,67^{\circ}$ (c $0.3 ; \mathrm{CHCl}_{3}$ ). Its molecular composition was determined as $\mathrm{C}_{29} \mathrm{H}_{46} \mathrm{O}_{2}$ by HR-TOFMS spectrum $\mathrm{m} / \mathrm{z} 449.3553[\mathrm{M}+\mathrm{Na}]^{+}$along with NMR data (Table 1), which indicates seven degrees of unsaturation. The UV spectrum shows no conjugated double bonds with maximum absorption above $200 \mathrm{~nm}$. The IR spectrum showed absorption band corresponding to the hydroxyl $\left(3423 \mathrm{~cm}^{-1}\right)$, aliphatic $\left(2926 \mathrm{~cm}^{-1}\right)$, carbonyl $\left(1736 \mathrm{~cm}^{-1}\right)$, olefinic $\left(1468 \mathrm{~cm}^{-1}\right)$, and $\mathrm{C}-\mathrm{O}$ bond from alcohol $\left(1040 \mathrm{~cm}^{-1}\right)$. The ${ }^{1} \mathrm{H}-\mathrm{NMR}$ spectrum showed the presence of 6 methyl groups, which consists of 2 protons resonating at $\delta_{\mathrm{H}} 0.55(\mathrm{Me}-$ $18)$ and $1.05(\mathrm{Me}-19)$ as singlet, 3 methyl at $\delta_{\mathrm{H}}$ $0.71(3 \mathrm{H}, d, J=3.6 \mathrm{~Hz}, \mathrm{Me}-21), 0.70(3 \mathrm{H}, d, J$ $=6.5 \mathrm{~Hz}, \mathrm{Me}-26), 0.88(3 \mathrm{H}, d, J=6.5 \mathrm{~Hz}, \mathrm{Me}-$ 27) as doublet and one at $\delta_{\mathrm{H}} 0.90(3 \mathrm{H}, d, J=$ 3.6, Me-29), as triplet. Three olefinic protons at $\delta_{\mathrm{H}} 5.55(1 \mathrm{H}, d, J=1.6, \mathrm{H}-6), 5.11(1 \mathrm{H}, d d, J$ $=15.2 \mathrm{~Hz}, \mathrm{H}-22)$ and $4.89(1 \mathrm{H}, d d, J=8.6,15.2$ $\mathrm{Hz}, \mathrm{H}-23)$ as well as an oxymethine proton at $\delta_{\mathrm{H}}$ 3.54 (br.s, H-7) were also observed in the ${ }^{1} \mathrm{H}$ NMR spectrum. The ${ }^{13} \mathrm{C}-\mathrm{NMR}$ together with DEPT spectra showed twenty nine carbon signals, which includes six methyls, eight methylenes, eight methines (including one oxygenated $s p^{3}$ carbons at $\left.\delta_{\mathrm{C}} 70.5\right)$, three $s p^{2}$ methines $\left(\delta_{\mathrm{C}} 126.1,138.0,129.4\right)$, two $s p^{3}$ quaternary carbons, one $s p^{2}$ quaternary carbons $\left(\delta_{\mathrm{C}} 165.7\right)$ and 1 carbonyl at $\delta_{\mathrm{C}} 202.3$. These unsaturation were calculated for eight out of the total seven degrees of unsaturation. All four degrees of unsaturation were consistent with the structure of tetracyclic stigmastane with additional carbonyl and olefin groups (Huang et al., 2009; Yan et al, 2014b).

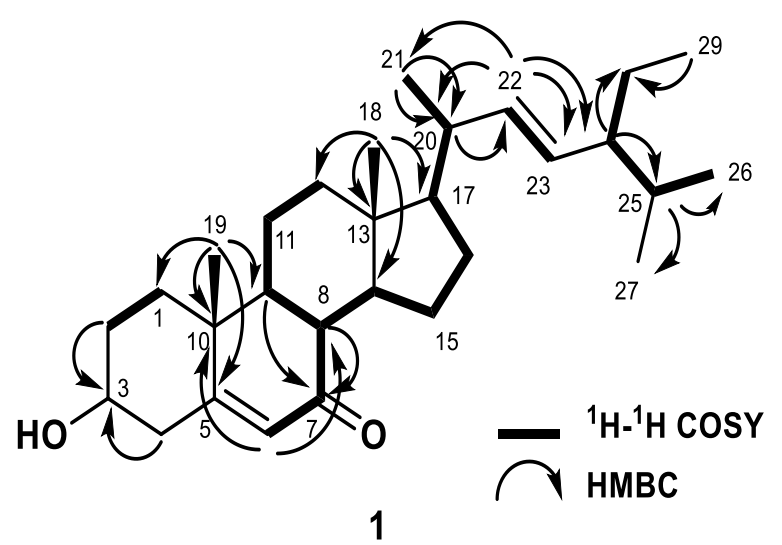

Figure 2. Selected $\mathrm{HMBC}$ and ${ }^{1} \mathrm{H}-{ }^{1} \mathrm{H}$ COSY correlations for $\mathbf{1}$.

A detailed comparison of the NMR data of 1 with those of 3-hydroxystigmast-4,22diene-7-one, isolated from Hedyotis diffusa (Cayme \& Ragasa, 2004), exhibited that the structures of the two compounds are very similar. The detail structure of $\mathbf{1}$ was supported from the ${ }^{1} \mathrm{H}-{ }^{1} \mathrm{H}$ COSY and HMBC experiments (Figure 2). The ${ }^{1} \mathrm{H}-{ }^{1} \mathrm{H}$ COSY spectrum of 
compound 1 showed correlations in $\mathrm{H}_{1}-\mathrm{H}_{2}, \mathrm{H}_{6}$ $\mathrm{H}_{7}-\mathrm{H}_{8}-\mathrm{H}_{9}-\mathrm{H}_{11}-\mathrm{H}_{12}, \mathrm{H}_{14}-\mathrm{H}_{15}-\mathrm{H}_{16}-\mathrm{H}_{17}-\mathrm{H}_{20}-\mathrm{H}_{22}-\mathrm{H}_{23}-$ $\mathrm{H}_{24}-\mathrm{H}_{25}-\mathrm{H}_{26}$, supporting the presence of stigmastane structure in compound $\mathbf{1}$. In the HMBC spectrum, the correlation of methyl protons to their neighboring carbons can influence the six methyls at C-10, C-13, C-20, C-25 (2 $\times)$, and C-29, respectively. The HMBC cross peak of the methylene protons at $\mathrm{H}-2\left(\delta_{\mathrm{H}}\right.$ 1.48 and 1.80) and $\mathrm{H}-4\left(\delta_{\mathrm{H}} 2.10\right.$ and 2.13) on an oxygenated carbon at $\delta_{\mathrm{C}} 70.5(\mathrm{C}-3)$, indicated the hydroxyl group is located at C-3. Correlation from methine proton $\delta_{\mathrm{H}} 1.91(\mathrm{H}-8)$ and $1.20(\mathrm{H}-$ 9) as well as an olefinic proton at $\delta_{\mathrm{H}} 5.55$ to $\delta_{\mathrm{C}}$ 202.3 (C-7) were used to assign a carbonyl group is located at C-7.

Table 1. NMR data for $\mathbf{1}\left(600 \mathrm{MHz}\right.$ for ${ }^{1} \mathrm{H}$ and $150 \mathrm{MHz}$ for ${ }^{13} \mathrm{C}$ in $\mathrm{CDCl}_{3}$ ).

\begin{tabular}{|c|c|c|c|c|c|c|}
\hline \multirow{3}{*}{ No } & \multicolumn{4}{|c|}{1} & \multicolumn{2}{|c|}{$\begin{array}{l}\text { 3-hydroxystigmasta-4,22-dien-7-one } \\
\text { (Cayme \& Ragasa, 2004) }\end{array}$} \\
\hline & $\begin{array}{l}{ }^{13} \mathrm{C}-\mathrm{NMR} \\
\end{array}$ & ${ }^{1}$ H-NMR & HMBC & COSY & ${ }^{13} \mathrm{C}-\mathrm{NMR}$ & ${ }^{1} \mathrm{H}-\mathrm{NMR}$ \\
\hline & $\delta_{\mathrm{C}} / \mathbf{p p m}$ & $\boldsymbol{\delta}_{\mathrm{C}} /$ Mult $(\mathrm{J} / \mathrm{Hz})$ & & & $\boldsymbol{\delta}_{\mathrm{C}} / \mathbf{p p m}$ & $\delta_{\mathrm{C}} / \mathrm{Mult}(\mathrm{J} / \mathrm{Hz})$ \\
\hline \multirow[t]{2}{*}{1} & 38.5 & $1.00 \mathrm{~m}$ & & 2 & 36.9 & $1.90 \mathrm{~m}$ \\
\hline & & $1.89 \mathrm{~m}$ & & & & $1.22 \mathrm{~m}$ \\
\hline \multirow[t]{2}{*}{2} & 31.1 & $1.48 \mathrm{~m}$ & 3 & 1 & 31.8 & $1.54 \mathrm{~m}$ \\
\hline & & $1.80 \mathrm{~m}$ & & & & $1.57 \mathrm{~m}$ \\
\hline 3 & 70.5 & 3.54 brs & & & 72.9 & $3.26 \mathrm{brs}$ \\
\hline \multirow[t]{2}{*}{4} & 45.4 & $2.10 d(2.34)$ & 3 & & 41.5 & $2.33 d(2.35)$ \\
\hline & & $2.13 d(2.34)$ & & & & $2.30 d(2.35)$ \\
\hline 5 & 165.7 & - & & & 166.5 & - \\
\hline 6 & 126.1 & $5.55 \mathrm{~d}(1.56)$ & $8,9,10$ & 7 & 126.8 & $5.86 d(1.58)$ \\
\hline 7 & 202.3 & - & & 6,8 & 200.8 & - \\
\hline 8 & 40.2 & $1.91 \mathrm{~m}$ & 7 & $7,9,14$ & 45.7 & $1.53 \mathrm{~m}$ \\
\hline 9 & 49.9 & $1.20 \mathrm{~m}$ & 7 & 8,11 & 50.3 & $1.37 \mathrm{~m}$ \\
\hline 10 & 36.0 & - & & & 38.9 & - \\
\hline \multirow[t]{2}{*}{11} & 26.0 & $2.19 \mathrm{~m}$ & & 9,12 & 21.3 & $1.61 \mathrm{~m}$ \\
\hline & & $0.99 \mathrm{~m}$ & & & & $1.63 \mathrm{~m}$ \\
\hline \multirow[t]{2}{*}{12} & 39.0 & $1.83 d t(13.03 \& 2.28)$ & & 11 & 39.8 & $2.05 d t(13.03 \& 2.28)$ \\
\hline & & $0.93 \mathrm{~m}$ & & & & $1.24 \mathrm{~m}$ \\
\hline 13 & 43.2 & - & & & 43.6 & - \\
\hline 14 & 54.7 & $0.96 m$ & & 8,15 & 50.4 & $1.53 \mathrm{~m}$ \\
\hline \multirow[t]{2}{*}{15} & 26.3 & $1.02 \mathrm{~m}$ & & 14,16 & 25.4 & $1.81 \mathrm{~m}$ \\
\hline & & $2.18 \mathrm{~m}$ & & & & $1.16 \mathrm{~m}$ \\
\hline \multirow[t]{2}{*}{16} & 40.2 & $1.85 \mathrm{~m}$ & & 15,17 & 25.6 & $1.82 \mathrm{~m}$ \\
\hline & & $1.36 \mathrm{~m}$ & & & & $1.36 \mathrm{~m}$ \\
\hline 17 & 49.9 & $1.20 \mathrm{~m}$ & & 16,20 & 56.5 & $1.27 \mathrm{~m}$ \\
\hline 18 & 11.9 & $0.55 s$ & $12,13,14,17$ & & 12.5 & $1.02 s$ \\
\hline 19 & 17.3 & $1.05 s$ & $1,5,9,10$ & & 19.8 & $1.32 s$ \\
\hline 20 & 39.7 & $0.97 m$ & & 17,21 & 36.3 & $2.13 \mathrm{~m}$ \\
\hline 21 & 21.2 & $0.71 d(3,6)$ & $17,20,22$ & 20 & 21.4 & $0.98 d(3.6)$ \\
\hline 22 & 138.0 & $5.11 d d(8.7 \& 15.12)$ & $20,21,23,24$ & 23 & 138.8 & $5.48 d d(8.7 \& 15.12)$ \\
\hline 23 & 129.4 & $4.89 d d(8.7 \& 15.12)$ & & 22 & 129.9 & $5.06 d d(8.7 \& 15.12)$ \\
\hline 24 & 50.3 & $2.36 \mathrm{~m}$ & 25,28 & 25,28 & 52.3 & $1.87 \mathrm{~m}$ \\
\hline 25 & 33.9 & $0.89 \mathrm{~m}$ & 26,27 & 24,26 & 26.5 & $1.60 \mathrm{~m}$ \\
\hline 26 & 19.7 & $0.70 d(6.48)$ & & 25 & 21.1 & $0.92 d(6.48)$ \\
\hline 27 & 19.0 & $0.88 d(6.48)$ & & & 19.5 & $0.91 d(6.48)$ \\
\hline \multirow[t]{2}{*}{28} & 21.2 & $1.85 \mathrm{~m}$ & & 24 & 34.6 & $0.90 \mathrm{~m}$ \\
\hline & & $0.63 \mathrm{~m}$ & & & 36.6 & $1.71 \mathrm{~m}$ \\
\hline 29 & 21.0 & $0.90 t(3.60)$ & & & 21.5 & $0.89 t(3.60)$ \\
\hline
\end{tabular}


The stereochemistry of 1 was identified by a NOESY experiment (Figure 3), in which the NOESY correlations between Me-19 and H3 indicated that the C-3 hydroxyl group is $\alpha$ oriented. Similar to the NOESY observations, the cross peak between Me-18 and H-20, indicated that Me-21 was $\alpha$-oriented. Furthermore, the NOESY cross peak, which was also observed between Me-21 / H-17, showed that the side chain at $\mathrm{C}-17$ was $\beta$-oriented. In addition, the correlation between $\mathrm{H}-24$ and $\mathrm{H}$ 17 , indicated that an ethyl chain was $\beta$-oriented. Therefore, the structure of compound 1 was determined to be $3 \alpha$-hydroxystigmast-5(6),22diene-7-one.

The known compounds stigmasterol (2) (Ragasa et al., 2014) and 3-hydroxystigmast-7 $\beta$ metoxy-5(6)-en (3) (Pettit et al., 2000) were identified by comparison with spectroscopic data with reported value. The presence of three steroids suggested that Dysoxylum genus can produce the steroid as one of the chemical markers.

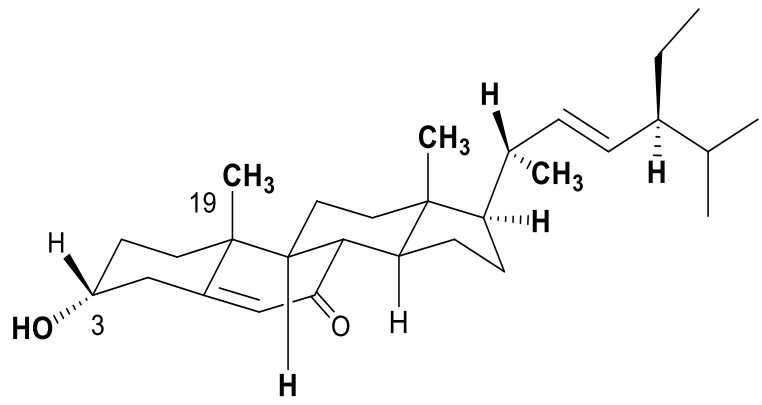

Figure 3. Selected NOESY correlations for $\mathbf{1}$.

The cytotoxic effect of the three isolated compounds 1-3 were conducted against MCF-7 breast cancer cells according to a modified method previously described (Skehan et al., 1990), using Cisplatin as a positive control, $\mathrm{IC}_{50}$ $3.20 \mathrm{mg} / \mathrm{mL}$ (Supratman et al., 2019; Hadisaputri et al., 2012). Furthermore, compound 1-3, showed cytotoxic activity with $\mathrm{IC}_{50}$ values of $20.13 \pm 0.06,100.28 \pm 0.06$ and $26.35 \pm 0.04 \mu \mathrm{M}$ respectively. The presence of carbonyl or methoxy group at the C-7 position increases the cytotoxic activity, replacing 7-OH on compound 1 with 7-OMe on compound $\mathbf{3}$ slightly reduces reactivity (Simon et al., 1998).

\section{CONCLUSIONS}

Three steroids, $3 \alpha$-Hydroxystigmast-5 (6), 22-Dien-7-en (1), as well as two well-known steroids, Stigmasterol (2) and 3-Hydroxy-7 $\beta$ - methoxystigmast-5 (6) -one (3) was isolated from the stem back of $D$. nutans. Compound 1 showed the strongest cytotoxic activity with an $\mathrm{IC}_{50}$ value of of $20.13 \pm 0.06 \mu \mathrm{M}$.

\section{ACKNOWLEDGEMENTS}

The work was partially funded by Universitas Padjadjaran (Academic Leadership Grant, ALG, 2020 by Unang Supratman). The author express profound gratitude to Mr. Ismail, the staff of the Bogoriense Herbarium, Bogor, Indonesia for plant identification, Ms. Mia Kusmiati Sukmana and Mr. Kansy Haikal at Central Laboratory, Universitas Padjadjaran, Jatinangor, Indonesia for cytotoxic assay and HR-TOFMS measurements.

\section{REFERENCES}

Cao P, Liang G, Gao X, Wang X, Li Z. 2013. Three new nor-dammarane triterpenoids from Dysoxylum hainanense with particular cytotoxicity against glioma cell line. Archives of Pharmacal Research. 36(3): 322-326.

Cayme JM, Ragasa CY. 2004. Structure elucidation of $\beta$-stigmasterol and $\beta$-sitosterol from Sesbania grandifora [Linn.] Pers. and $\beta$ carotene from Heliotropium indicum Linn. by NMR spectroscopy. Kimika. 20(1): 5-12.

Das M, Saikia PJ, Sarma HN. 2013. Crude bark extract of Dysozylum alliarium induces alteration in histological structures and VEGF-C expression in uterus during days 4-7 of gestation in albino rat. Reproductive Medicine and Biology. 12(3): 85-98.

Farabi K, Harneti D, Nurlelasari MR, Hidayat AC, Supratman U, Awang K, Shiono Y. 2017. Cytotoxic steroids from the bark of Aglaia argentea (Meliaceae). CMU Journal of Natural Sciences. 16(4): 293-306.

Gopalakrishnan S, Lakshmi SYS, Banu F. 2015. Comparison of antimicrobial activities of silver nanoparticles synthesized from Dysoxylum parasiticum. Indian Journal of Medicine and Healthcare. 4(2): 1-5.

Govindachari TR, Suresh G, Kumari K, Rajamannar T, Partho PD. 1999. Nymania-3: a bioactive triterpenoid from Dysoxylum malabaricum. Fitoterapia (Milano). 70(1): 83-86.

Hadisaputri YE, Miyazaki T, Suzuki S, Yokobori T, Kobayashi T, Tanaka N, Inose T, Sohda M, 
Kuwano H. 2012. TNFAIP8 overexpression: clinical relevance to esophageal squamous cell carcinoma. Annals of surgical oncology. 19(3): 589-96.

Han ML, Zhao JX, Liu HC, Ni G, Ding J, Yang SP, Yue JM. 2015. Limonoids and Triterpenoids from Dysoxylum mollissimum var. glaberrimum. Journal of Natural Products. 78(4): 754-761.

Heyne, K. 1982. "The Useful Indonesian Plants", Research and Development Agency, Ministry of Forestry, Jakarta, Indonesia, 729-740.

Hu J, Song Y, Li H., Yang B, Mao X, Zhao Y, Shi X. 2014a. Cytotoxic and anti-inflammatory tirucallane triterpenoids from Dysoxylum binectariferum. Fitoterapia. 99: 86-91.

Hu J, Song Y, Li H, Mao X, Zhao Y, Shi X, Yang B. 2014b. Antibacterial and cytotoxic triterpenoids from the ethanol extract of Dysoxylum densiflorum (Blume) Miq. Phytochemistry Letters. 10: 219-223.

Huang HL, Wang CM, Wang ZH, Yao MJ, Han GT, Yuan JC, Gao K, Yuan CS. 2011. Tirucallanetype triterpenoids from Dysoxylum lenticellatum. Journal of Natural Products. 74(10): 2235-2242.

Huang W, Li Y, Jiang J. 2009. Chemical constituents from Hedyotis diffusa. China Journal of Chinese Materia Medica. 34(6): 712-4.

Ismail IS, Nagakura Y, Hirasawa Y, Hosoya T, Lazim MIM, Lajis NH, Morita H. 2009. Acutaxylines A and B, two novel triterpenes from Dysoxylum acutangulum. Tetrahedron Letters. 50(34): 4830-4832.

Jiang K, Chen LL, Wang SF, Wang Y, Li Y, Gao K. 2015. Anti-inflammatory terpenoids from the leaves and twigs of Dysoxylum gotadhora. Journal of Natural Products. 78(5): 1037-1044.

Kurimoto SI, Kashiwada Y, Lee KH, Takaishi Y. 2011. Triterpenes and a triterpene glucoside from Dysoxylum cumingianum. Phytochemistry. 72(17): 22052211.

Luo XD, Wu SH, Wu DG, Ma YB, Qi SH. 2002. Novel antifeeding limonoids from Dysoxylum hainanense. Tetrahedron. 58(39): 7797-7804.

Lakshmi V, Pandey K, Kapil A, Singh N, Samant M,
Dube A. 2007. In vitro and in vivo leishmanicidal activity of Dysoxylum binectariferum and its fractions against Leishmania donovani. Phytomedicine. 14(1): 36-42.

Pettit GR, Numata A, Cragg GM, Herald DL, Takada $\mathrm{T}$, Iwamoto $\mathrm{C}$, Riesen $\mathrm{R}$, Schmidt JM, Doubek DL, Goswami A. 2000. Isolation and structures of schleicherastatins $1-7$ and schleicheols 1 and 2 from the teak forest medicinal tree Schleichera oleosa. Journal of Natural Products. 63(1): 72-8.

Ragasa CY, Ng VAS, De Los Reyes MM, Mandia EH, Oyong GG, Shen CC. 2014. Chemical constituents and cytotoxicity of the leaves of Dysoxylum gaudichaudianum (A. Juss.) Miq. Der Pharma Chemica. 6(5): 182-187.

Skehan P, Storeng R, Scudiero D, Monks A, McMahon J, Vistica D, Warren JT, Bokesch H, Kenney S, Boyd MR. 1990. New colorimetric cytotoxicity assay for anticancerdrug screening. JNCI: Journal of the National Cancer Institute. 82(13): 1107-1112.

Simon A, Allais DP, Duroux JL, Basly JP, DurandFontanier S, Delage. 1998. Inhibitory effect of curcuminoids on MCF-7 cell proliferation and structure-activity relationships. Cancer Letters. 129(1):111-116.

Supratman U, Naibaho W, Salam S, Maharani R, Hidayat AT, Harneti D, Nurlelasari, Shiono Y. 2019. Cytotoxic triterpenoids from the bark of Chisocheton patens Blume (Meliaceae). Phytochemistry letters. 30: 81-7.

Tang T, Liao SG, Na Z, Li Y, Xu YK. 2012. Dysoxylentin A, the first 21-nortriterpenoid bearing a 2-(propan-2-ylidenyl) furan-3 $(2 \mathrm{H})$ one, from Dysoxylum lenticellatum. Tetrahedron Letters. 53(9): 1183-1185.

Wah LK, Abas F, Cordell GA, Ito H, Ismail IS. 2013. Steroids from Dysoxylum grande (Meliaceae) leaves. Steroids. 78(2): 210-219.

aYan HJ, Wang JS, Kong LY. 2014. Cytotoxic dammarane-type triterpenoids from the stem bark of Dysoxylum binecteriferum. Journal of Natural Products. 77(2): 234-242.

bYan HJ, Wang JS, Kong LY. 2014. Cytotoxic steroids from the leaves of Dysoxylum binectariferum. Steroids. 86: 26-31. 
Zhang XY, Li Y, Wang YY, Cai XH, Feng T, Luo XD. 2010. Tirucallane-type alkaloids from the bark of Dysoxylum laxiracemosum. Journal of Natural Products. 73(8): 1385-1388.

Zhou B, Shen Y, Wu Y, Leng Y, Yue JM. 2015. Limonoids with $11 \beta$-Hydroxysteroid Dehydrogenase Type 1 Inhibitory Activities from Dysoxylum mollissimum. Journal of Natural Products. 78(8): 2116-2122.

Zou YH, Liu WT, Zhang JX, Xiang DC. 2017. Triterpenoids from the bark of Dysoxylum hainanense and their anti-inflammatory and radical scavenging activity. Fitoterapia. 121: 159-163. 